\title{
Relationships between Iymphocyte counts and treatment- related toxicities and clinical responses in patients with solid tumors treated with PD-1 checkpoint inhibitors
}

\author{
Adam Diehl'1 , Mark Yarchoan², Alex Hopkins², Elizabeth Jaffee ${ }^{2}$ and Stuart A. \\ Grossman ${ }^{2}$ \\ ${ }^{1}$ Department of Medicine at The Johns Hopkins Hospital, Baltimore, MD, USA \\ ${ }^{2}$ The Sidney Kimmel Comprehensive Cancer Center at Johns Hopkins, Baltimore, MD, USA \\ Correspondence to: Stuart A. Grossman, email: grossman@jhmi.edu \\ Keywords: lymphopenia; PD-1 inhibitor; response; immune-related adverse event; radiation \\ Received: July 27, $2017 \quad$ Accepted: November 28, 2017 Published: December 14, 2017 \\ Copyright: Diehl et al. This is an open-access article distributed under the terms of the Creative Commons Attribution License 3.0 \\ (CC BY 3.0), which permits unrestricted use, distribution, and reproduction in any medium, provided the original author and source \\ are credited.
}

\section{ABSTRACT}

The relationships between absolute lymphocyte counts (ALC), drug- related toxicities, and clinical responses remain unclear in cancer patients treated with PD-1 (programmed cell death 1) inhibitors. We performed a retrospective review of 167 adult solid tumor patients treated with nivolumab or pembrolizumab at a single institution between January 2015 and November 2016. Patients with an ALC $>2000$ at baseline had an increased risk of irAE (OR 1.996, p<0.05) on multivariate analysis. In a multivariate proportional hazards model, a shorter time to progression was noted in patients who were lymphopenic at baseline (HR $1.45(p<0.05)$ ) and at three months (HR $2.01(p<0.05)$ ). Patients with baseline lymphopenia and persistent Iymphopenia at month 3 had a shorter time to progression compared to those who had baseline lymphopenia but recovered with ALC > 1000 at 3 months (HR 2.76, $\mathbf{p}<\mathbf{0 . 0 5}$ ). Prior radiation therapy was the characteristic most strongly associated with lymphopenia at 3 months (OR 2.24, p<0.001). These data suggest that patients with higher baseline lymphocyte counts have a greater risk for irAE, whereas patients with lymphopenia at baseline and persistent lymphopenia while on therapy have a shorter time to progression on these agents. These associations require further validation in additional patient cohorts.

\section{INTRODUCTION}

Programmed cell death protein 1 (PD-1) is a molecule that modulates cellular immunity to limit autoimmunity, but can also be co-opted by cancers and infections to create immune tolerance [1]. Nivolumab and pembrolizumab are fully human IgG4 programmed death 1 (PD-1) checkpoint-inhibitor antibodies that selectively block the interaction of the $\mathrm{PD}-1$ receptor with its two known ligands, programmed death ligand 1 and 2 (PD-L1 and PD-L2). By blocking the interaction of PD-1 with its ligands, these therapies halt the negative signal that downregulates T-cell activation [2]. Nivolumab and pembrolizumab have significant clinical activity in multiple tumor types, including squamous and nonsquamous non-small-cell lung cancer, melanoma, renal cell carcinoma (RCC), urothelial carcinoma, and head and neck squamous cell carcinoma (HNSCC) [3-11]. Overall response rates have been up to $30-40 \%$ for melanoma, up to $20 \%$ for NSCLC, and up to $25 \%$ in RCC treated with PD-1 inhibitor monotherapy; however, the most remarkable aspect of this novel drug class is the durability of responses observed in a subgroup of responders [11].

Inhibition of the PD-1 checkpoint can result in immune activation in non-target tissues, resulting in immune-related adverse events (irAE) in a subset of 
patients. The risk of irAEs is higher in patients receiving PD-1 inhibitor therapy in combination with other immune checkpoint therapies such as ipilimumab, an inhibitor of cytotoxic T-lymphocyte-associated protein 4 (CTLA-4). For patients receiving combination therapy with a PD-1 and CTLA-4 inhibitor, the rate of grade 3 or 4 adverse events is as high as $55 \%[12]$.

The discovery of factors that influence the clinical response to immunotherapy remains an area of active research and is important to maximizing the benefit/ risk ratio of these agents in clinical practice. Moreover, factors that serve as a marker of anti-tumor effect can aid in the discovery of new immunotherapy combinations that augment sub-optimal responses to monotherapy. In this single center retrospective cohort study of patients receiving PD-1 inhibitor therapy for solid tumors, we analyzed the relationship between absolute lymphocyte count (ALC) and rates of irAEs and objective responses.

\section{RESULTS}

Of the 167 patients included in our analysis, 54 had lung cancer, 60 had melanoma, 25 had RCC, 12 had urothelial, 8 had HNSCC, 6 had Merkel cell carcinoma, and 2 had MMR-d colon cancer. Patient and treatment characteristics are contained in Table 1. Nivolumab was prescribed to $75 \%$ of patients, with all others receiving pembrolizumab. Fifty-one percent had received prior radiation therapy and $75 \%$ had received prior chemotherapy. Eleven percent of patients received prior ipilimumab therapy as one of their prior chemotherapy lines, and $17 \%$ of patients received concurrent ipilimumab therapy with their PD-1 inhibitor. At database lock, 53\% of patients were on therapy with a PD-1 inhibitor. The median duration on therapy with the PD-1 inhibitor was 6.6 months. The median baseline and three-month absolute lymphocyte counts (ALC) were 1310 and 1220, respectively. Lymphopenia (ALC $<1000$ ) was present in $29.9 \%$ and $31.0 \%$ at baseline and 3 months after treatment initiation, respectively. The median follow-up time was 9.6 months with the longest follow-up time of 111 months. In this limited follow-up time, there were 21 deaths in total leading to an overall survival of $87.4 \%$. There were 68 responders (15 CR and $53 \mathrm{PR}$ ), yielding an overall response rate of $41 \%$. Ultimately, 74 patients (44\%) developed progressive disease with or without an initial response to therapy and the median time to progression was 2.8 months.

\section{Patient characteristics associated with lymphopenia}

Table 1 contains percentages of patients with various demographic and treatment characteristics including stratification by response to therapy as well as occurrence of irAE. In univariate analysis, the frequency of lymphopenia (ALC $<1000)$ at baseline was no different in those who had received prior radiation and those who had not. However, at 3 months after the start of therapy, the frequency of lymphopenia was significantly higher in those who received prior radiation therapy $(\mathrm{p}=0.0001)$. There was no difference in lymphopenia at 3 months between those who had received prior conventional radiation therapy versus prior stereotactic body radiation therapy (SBRT). A similar, but non-significant, trend was seen in those with prior chemotherapy. In univariate analysis, there was no association between prior chemotherapy and baseline lymphopenia. In a multiple logistic regression model including age, sex, ethnicity, tumor type, PD-1 inhibitor used, prior chemotherapy, prior radiation therapy, concurrent ipilimumab and occurrence of irAE, prior radiation therapy was the most significantly associated with lymphopenia at 3 months with OR $2.24(p<0.001)$. In this multivariate model, there was no association between prior radiation therapy and lymphopenia at baseline, consistent with the univariate analysis. In addition, there was no association between prior chemotherapy and lymphopenia at baseline or 3 months in the multivariate model. In addition to prior radiation therapy, tumor type was significantly associated with lymphopenia at baseline $(\mathrm{p}<0.01)$ and at 3 months $(\mathrm{p}<0.05)$ in this multiple logistic regression model, owing to significantly less lymphopenia in those with melanoma relative to other tumor types.

\section{Relationship between baseline lymphocyte counts and drug-related ir $\mathrm{AE}$}

A total of 51 patients $(30.5 \%)$ in this patient population experienced an adverse event of any grade with a median time to develop an irAE of 2.6 months. Categorized by the highest grade irAE experienced, 17 patients (10.1\%) experienced Grade 1 irAE, 19 (11.3\%) experienced Grade 2 irAE, 13 (7.8\%) experienced Grade 3 irAE, and $2(1.2 \%)$ experienced Grade 4 irAE. Of those with an irAE, $43(84 \%)$ required treatment with 32 $(63 \%)$ requiring systemic steroids and $1(2 \%)$ requiring an immunosuppressive therapy beyond steroids (TNFa inhibitor), 18 (35\%) required therapy discontinuation due to the irAE, and $5(9.8 \%)$ required hospitalization for their irAE. A list of the various irAE that occurred are shown in Table 2.

In univariate analysis, a baseline ALC $>2000$ as well as an ALC > 2000 at one month into therapy were associated with increased risk of irAE of grade $\geq 2$ $(\mathrm{p}<0.01)$. In addition, an ALC $>2000$ at one month into therapy was associated with increased risk of all irAE $(\mathrm{p}<0.05)$ and irAE requiring treatment $(\mathrm{p}<0.01)$. This relationship did not hold for a lower ALC cutoff of 1000. A multiple logistic regression analysis including age, sex, ethnicity, tumor type, PD-1 inhibitor used, number of prior chemotherapies, prior radiation, and concurrent 
Table 1: Patient characteristics

\begin{tabular}{|c|c|c|c|c|c|c|c|c|}
\hline & Number & $\%$ & $\begin{array}{c}\% \text { in } \\
\text { those with } \\
\text { irAE }\end{array}$ & $\begin{array}{c}\% \text { in those } \\
\text { without } \\
\text { irAE }\end{array}$ & P value & $\begin{array}{c}\% \text { in } \\
\text { those with } \\
\text { response }\end{array}$ & $\begin{array}{l}\% \text { in those } \\
\text { without a } \\
\text { response }\end{array}$ & $P$ value \\
\hline \multicolumn{9}{|l|}{ Gender } \\
\hline Male & 99 & $59.28 \%$ & 59 & 60 & \multirow{2}{*}{$\mathrm{P}=1.000$} & 54 & 63 & \multirow[t]{2}{*}{$\mathrm{P}=0.337$} \\
\hline Female & 68 & $40.71 \%$ & 41 & 40 & & 46 & 37 & \\
\hline \multicolumn{9}{|l|}{ Age } \\
\hline$<50$ & 18 & $10.78 \%$ & 14 & 10 & $\mathrm{P}=0.425$ & 12 & 10 & $\mathrm{P}=0.802$ \\
\hline $50-75$ & 118 & $70.66 \%$ & 67 & 72 & $\mathrm{P}=0.465$ & 72 & 70 & $\mathrm{P}=0.862$ \\
\hline$>75$ & 31 & $18.56 \%$ & 20 & 18 & $\mathrm{P}=0.831$ & 16 & 20 & $\mathrm{P}=0.550$ \\
\hline \multicolumn{9}{|l|}{ Race } \\
\hline White & 136 & $81.43 \%$ & 92 & 76 & \multirow{5}{*}{$\mathrm{P}=0.0685$} & 88 & 77 & \multirow[t]{5}{*}{$\mathrm{P}=0.181$} \\
\hline Black & 22 & $13.17 \%$ & 4 & 17 & & 11 & 15 & \\
\hline Hispanic & 4 & $2.40 \%$ & 4 & 2 & & 0 & 4 & \\
\hline Asian & 3 & $1.80 \%$ & 0 & 3 & & 0 & 3 & \\
\hline Other & 2 & $1.20 \%$ & 0 & 2 & & 1 & 1 & \\
\hline \multicolumn{9}{|l|}{ Tumor Type } \\
\hline Lung & 54 & $32.34 \%$ & 23 & 36 & \multirow{6}{*}{$\mathrm{P}=0.0065$} & 21 & 41 & \multirow[t]{6}{*}{$\mathrm{P}=0.0004$} \\
\hline Melanoma & 60 & $35.93 \%$ & 57 & 27 & & 53 & 24 & \\
\hline $\mathrm{RCC}$ & 25 & $14.97 \%$ & 12 & 16 & & 7 & 20 & \\
\hline HNSCC & 8 & $4.79 \%$ & 0 & 7 & & 4 & 5 & \\
\hline Urothelial & 12 & $7.19 \%$ & 6 & 8 & & 12 & 4 & \\
\hline $\begin{array}{l}\text { Other (Merkel Cell } \\
\text { Carcinoma, Colon } \\
\text { Cancer) }\end{array}$ & 8 & $4.79 \%$ & 2 & 6 & & 3 & 6 & \\
\hline \multicolumn{9}{|l|}{ PD1 Inhibitor } \\
\hline Pembrolizumab & 42 & $25.00 \%$ & 25 & 25 & \multirow{2}{*}{$\mathrm{P}=1.000$} & 35 & 18 & \multirow[t]{2}{*}{$\mathrm{P}=0.018$} \\
\hline Nivolumab & 125 & $75.00 \%$ & 75 & 75 & & 65 & 82 & \\
\hline \multicolumn{9}{|l|}{ Prior XRT } \\
\hline No & 82 & $49.10 \%$ & 57 & 46 & \multirow{2}{*}{$\mathrm{P}=0.239$} & 54 & 45 & \multirow[t]{2}{*}{$\mathrm{P}=0.273$} \\
\hline Yes & 85 & $50.90 \%$ & 43 & 54 & & 46 & 55 & \\
\hline \multicolumn{9}{|c|}{ Prior Chemotherapy } \\
\hline No & 42 & $25.10 \%$ & 43 & 17 & \multirow{2}{*}{$\mathrm{P}=0.0008$} & 29 & 22 & \multirow[t]{2}{*}{$\mathrm{P}=0.364$} \\
\hline Yes & 125 & $74.90 \%$ & 57 & 83 & & 71 & 78 & \\
\hline \multicolumn{9}{|l|}{ Prior Ipilimumab } \\
\hline No & 148 & $88.62 \%$ & 82 & 91 & \multirow{2}{*}{$\mathrm{P}=0.113$} & 85 & 91 & \multirow[t]{2}{*}{$\mathrm{P}=0.323$} \\
\hline Yes & 19 & $11.38 \%$ & 18 & 9 & & 15 & 9 & \\
\hline
\end{tabular}

(Continued) 


\begin{tabular}{|c|c|c|c|c|c|c|c|c|}
\hline & Number & $\%$ & $\begin{array}{c}\% \text { in } \\
\text { those with } \\
\text { irAE }\end{array}$ & $\begin{array}{c}\% \text { in those } \\
\text { without } \\
\text { irAE }\end{array}$ & Pvalue & $\begin{array}{c}\% \text { in } \\
\text { those with } \\
\text { response }\end{array}$ & $\begin{array}{l}\% \text { in those } \\
\text { without a } \\
\text { response }\end{array}$ & P value \\
\hline \multicolumn{9}{|c|}{ Number of Prior Chemotherapy Regimens } \\
\hline 1 & 76 & $60.80 \%$ & 73 & 57 & \multirow{7}{*}{$\mathrm{P}=0.012$} & 56 & 64 & \multirow[t]{7}{*}{$\mathrm{P}=0.423$} \\
\hline 2 & 26 & $20.80 \%$ & 14 & 23 & & 29 & 16 & \\
\hline 3 & 14 & $11.20 \%$ & 7 & 13 & & 13 & 10 & \\
\hline 4 & 6 & $4.80 \%$ & 3 & 5 & & 2 & 7 & \\
\hline 5 & 1 & $0.80 \%$ & 0 & 1 & & 0 & 1 & \\
\hline 6 & 1 & $0.80 \%$ & 0 & 1 & & 0 & 1 & \\
\hline 7 & 1 & $0.80 \%$ & 3 & 0 & & 0 & 1 & \\
\hline \multicolumn{9}{|c|}{ Concurrent Treatment with Ipilimumab } \\
\hline No & 139 & $83.23 \%$ & 69 & 90 & \multirow{2}{*}{$\mathrm{P}=0.0014$} & 75 & 89 & \multirow[t]{2}{*}{$\mathrm{P}=0.021$} \\
\hline Yes & 28 & $16.77 \%$ & 31 & 10 & & 25 & 11 & \\
\hline \multicolumn{9}{|l|}{ Death } \\
\hline No & 146 & $87.43 \%$ & 86 & 88 & \multirow{2}{*}{$\mathrm{P}=0.802$} & 97 & 81 & \multirow[t]{2}{*}{$P=0.0016$} \\
\hline Yes & 21 & $12.57 \%$ & 14 & 12 & & 3 & 19 & \\
\hline \multicolumn{9}{|c|}{ Immune Related Adverse Event } \\
\hline No & 116 & $69.46 \%$ & & & & 63 & 74 & \multirow[t]{2}{*}{$\mathrm{P}=0.173$} \\
\hline Yes & 51 & $30.54 \%$ & & & & 37 & 26 & \\
\hline \multicolumn{9}{|l|}{ Number of irAE } \\
\hline 1 & 39 & $76.47 \%$ & & & & 68 & 85 & \multirow[t]{3}{*}{$\mathrm{P}=0.221$} \\
\hline 2 & 10 & $19.61 \%$ & & & & 24 & 15 & \\
\hline 3 & 2 & $3.82 \%$ & & & & 8 & 0 & \\
\hline \multicolumn{9}{|c|}{ Immune Related Adverse Event Requiring Treatment } \\
\hline No & 43 & $25.75 \%$ & & & & 66 & 80 & \multirow[t]{2}{*}{$\mathrm{P}=0.071$} \\
\hline Yes & 124 & $74.25 \%$ & & & & 34 & 20 & \\
\hline \multicolumn{9}{|c|}{ Immune Related Adverse Event Grade } \\
\hline 1 & 17 & $33.33 \%$ & & & & 63 & 74 & \multirow[t]{5}{*}{$\mathrm{P}=0.526$} \\
\hline 2 & 19 & $37.25 \%$ & & & & 10 & 10 & \\
\hline 3 & 13 & $25.49 \%$ & & & & 16 & 8 & \\
\hline 4 & 2 & $3.92 \%$ & & & & 9 & 7 & \\
\hline $\begin{array}{l}\text { Median Treatment } \\
\text { Duration (months) }\end{array}$ & 6.6 & & 6.06 & 6.68 & & 11.13 & 4.66 & \\
\hline $\begin{array}{l}\text { Mean Treatment } \\
\text { Duration (months) }\end{array}$ & 9.16 & & 9.18 & 9.14 & $\mathrm{P}=0.976$ & 12.9 & 6.58 & $\mathrm{P}<0.0001$ \\
\hline
\end{tabular}

Table of patient and treatment characteristics including demographics, tumor type, PD-1 inhibitor used, prior treatments, immune-related adverse events and treatment duration with comparisons between those with and without response and with and without irAE. P values greater than 0.05 indicate no significant difference in the characteristic between those with and without irAE or those with and without response. The P value was calculated using the appropriate statistical test (2-tailed Fisher's exact test for binary data, Pearson's chi-squared test for sets of categorical data, $t$ test for continuous dependent variable). 
Table 2: irAE types and grades

\begin{tabular}{|c|c|c|c|c|}
\hline $\begin{array}{l}\text { Immune related } \\
\text { adverse event }\end{array}$ & $\begin{array}{l}\text { Any grade (number } \\
\text { of patients) }\end{array}$ & $\begin{array}{c}\text { Any grade (\% of all } \\
\text { patients) }\end{array}$ & $\begin{array}{c}\text { Grade } 3 \text { or } 4 \text { (number } \\
\text { of patients) }\end{array}$ & $\begin{array}{c}\text { Grade } 3 \text { or } 4(\% \text { of } \\
\text { all patients) }\end{array}$ \\
\hline All irAE & 51 & 30.4 & 15 & 8.9 \\
\hline \multicolumn{5}{|l|}{ Skin } \\
\hline Pruritis & 1 & 0.6 & 0 & 0.0 \\
\hline Vitiligo & 3 & 1.8 & 0 & 0.0 \\
\hline Rash & 19 & 11.3 & 2 & 1.2 \\
\hline GI & & & & 0.0 \\
\hline Pancreatitis & 2 & 1.2 & 1 & 0.6 \\
\hline Enteritis/Colitis & 5 & 3.0 & 2 & 1.2 \\
\hline Diarrhea & 3 & 1.8 & 0 & 0.0 \\
\hline Hepatitis & 6 & 3.6 & 3 & 1.8 \\
\hline \multicolumn{5}{|l|}{ Musculoskeletal } \\
\hline Myasthenia Gravis & 1 & 0.6 & 1 & 0.6 \\
\hline Arthritis & 4 & 2.4 & 1 & 0.6 \\
\hline \multicolumn{5}{|l|}{ Nervous System } \\
\hline Sensory neuropathy & 1 & 0.6 & 0 & 0.0 \\
\hline \multicolumn{5}{|l|}{ Pulmonary } \\
\hline Pneumonitis & 9 & 5.4 & 2 & 1.2 \\
\hline \multicolumn{5}{|l|}{ Ophthalmologic } \\
\hline Optic Neuritis & 1 & 0.6 & 1 & 0.6 \\
\hline \multicolumn{5}{|l|}{ Renal } \\
\hline Nephritis & 1 & 0.6 & 0 & 0.0 \\
\hline \multicolumn{5}{|l|}{ Heme } \\
\hline Thrombocytopenia & 1 & 0.6 & 1 & 0.6 \\
\hline \multicolumn{5}{|l|}{ Endocrine } \\
\hline Adrenal Insufficiency & 1 & 0.6 & 0 & 0.0 \\
\hline Hypothyroidism & 4 & 2.4 & 0 & 0.0 \\
\hline Hypophysitis & 3 & 1.8 & 1 & 0.6 \\
\hline Sjogren's disease & 1 & 0.6 & 0 & 0.0 \\
\hline
\end{tabular}

Table listing all the various types of irAE that occurred including the number and percentage of high grade irAE.

ipilimumab therapy, revealed that an ALC $>2000$ at the start of therapy was associated with a higher incidence of irAE of grade $\geq 2$ (OR 1.996, $\mathrm{p}<0.05)$, as was an ALC $>2000$ at 1 month into therapy (OR 1.813, p<0.05). An association between irAE of grade $\geq 2$ and higher absolute eosinophil count was also noted. Further details of this multiple logistic regression analysis are provided in Table 3.

\section{Relationship between lymphopenia and tumor progression}

In univariate survival analysis, the median time to progression was significantly shorter in patients with baseline lymphopenia (13.9 months versus median not reached, $\mathrm{p}<0.01)$. Similarly, patients with lymphopenia at 3 months after initiation of treatment progressed more 
Table 3: Hazard and odds ratios for multivariate models of progression and irAE occurrence

\section{Cox proportional hazards model variable}

$\mathrm{ALC}<1000$ at

baseline

ALC $<1000$ at 3

months

Difference Between

ALC at 3 months and

at Baseline

Difference Between

$\mathrm{ALC}$ at 3 months

and at Baseline for

increments of 100

ALC at Baseline

ALC at Baseline for

increments of 100

$\mathrm{ALC}$ at 3 months

ALC at 3 months for increments of 100

ANC/ALC ratio at 3 months

with Persistence at 3

months (vs Recovery

at 3 months)

Baseline Lymphopenia

with Persistence at

3 months (vs Never

Lymphopenic)

Baseline Lymphopenia

with Recovery at 3

months (vs Never

Lymphopenic)

No Baseline

Lymphopenia with

New Lymphopenia at

3 months (vs Never

Lymphopenic)

No Baseline

Lymphopenia with

New Lymphopenia at

3 months (vs Always

Lymphopenic)

1.445

2.008

1.001

1.116

0.999

0.947

0.999

0.882

1.496

1.061

2.451

3.093
Hazard ratio Upper 95\% CI $\quad$ Lower 95\% CI $\quad$ Wald test, P

1.941

1.076

0.0145

2.798

1.441

$<0.0001$

1.002

1.001

$<0.0001$

1.178

1.058

$<0.0001$

1.000

0.999

0.0358

0.996

0.901

0.0334

0.999

0.998

0.0004

0.946

0.824

0.0004

1.313

1.138

$<0.0001$

2.156

1.039

0.0305

1.992

0.566

0.8530

4.053

1.483

0.0005

7.050

1.355

0.0073

(Continued) 


\begin{tabular}{llccc}
\hline $\begin{array}{l}\text { Multiple logistic } \\
\text { regression of grade } \\
\text { >= } \mathbf{2} \text { irAE model } \\
\text { variable }\end{array}$ & OR & $\mathbf{9 5 \%}$ CI & $\mathbf{9 5 \%}$ CI & $\begin{array}{c}\text { Likelihood ratio test, } \\
\text { P }\end{array}$ \\
\hline $\begin{array}{l}\text { ALC }>2000 \text { at } \\
\text { baseline }\end{array}$ & 1.996 & 3.490 & 1.155 & 0.0136 \\
$\begin{array}{l}\text { ALC }>2000 \text { at } 1 \\
\text { month }\end{array}$ & 1.813 & 3.248 & 1.030 & 0.039 \\
$\begin{array}{l}\text { AEC at baseline } \\
\text { AEC at baseline for } \\
\text { increments of } 100\end{array}$ & 1.003 & 1.006 & 1.000 & 0.027 \\
$\begin{array}{l}\text { AEC at } 1 \text { month } \\
\text { (excluding those who } \\
\text { received steroids } \\
\text { within } 1 \text { month) }\end{array}$ & 1.340 & 1.742 & 1.035 & 0.027 \\
$\begin{array}{l}\text { AEC at } 1 \text { month } \\
\text { (excluding those who } \\
\text { received steroids } \\
\text { within } 1 \text { month) for } \\
\text { increments of } 100\end{array}$ & 1.002 & 1.004 & 1.000 & 0.0268 \\
\hline
\end{tabular}

Table of hazard ratios (HR) with corresponding confidence intervals (CI) and $p$ values derived from a Cox proportional hazards model of progression, respectively, as well as OR, CI and $\mathrm{p}$ values derived from a multivariate logistic regression model of grade $\geq 2$ irAE for the listed variables, adjusted for age, sex, ethnicity, tumor type, PD-1 inhibitor used, number of prior chemotherapies, prior radiation, and concurrent ipilimumab therapy.

rapidly than other patients (4.6 months vs median not reached, $\mathrm{p}<0.0001)$. In patients who were lymphopenic at baseline and had persistent lymphopenia at month 3 , median time to progression was 10.2 months, which was significantly shorter than those who had no baseline lymphopenia (median not reached) $(\mathrm{p}<0.01)$. However, progression free survival was longer in patients who had baseline lymphopenia but recovered their ALC to greater than 1000 at 3 months (median not reached) $(\mathrm{p}<0.05)$. There was no significant difference in time to progression between those with no lymphopenia and those with baseline lymphopenia who recovered with ALC $>1000$ at 3 months after the start of therapy (median not reached for either) $(\mathrm{p}=0.51)$. Patients who were not lymphopenic at baseline but who became lymphopenic at 3 months had a median time to progression of 3.5 months while those with persistently normal lymphocyte counts fared significantly better (median not reached) $(\mathrm{p}<0.0001)$. There was also an association found with absolute eosinophil count $>200$ at 1 month as shown in Figure 1 and Table 4.

In a Cox proportional hazards model for progression adjusted for age, sex, ethnicity, tumor type, PD-1 inhibitor use, prior radiation therapy, number of prior chemotherapies, concurrent ipilimumab therapy and occurrence of immune-related adverse events, there were a number of associations with lymphopenia and progression as shown in Table 3. Baseline lymphopenia
$($ ALC $<1000)$ had a significant increased risk of progression with a hazard ratio $1.45(\mathrm{p}<0.05)$. Baseline ALC as a continuous variable was also associated with progression with hazard ratio 0.947 for every increase in ALC of $100(p<0.05)$. In the same model, lymphopenia at 3 months after the start of therapy had an even more significant increased risk of progression with a hazard ratio $2.01(\mathrm{p}<0.0001)$. Of those patients with lymphopenia at baseline, 30 patients $(68 \%)$ had persistent lymphopenia (ALC $<1000$ at baseline persisting to month 3) whereas 14 patients (32\%) had normalized lymphocyte counts by month 3 . In those patients who were lymphopenic at baseline and had persistent lymphopenia at month 3, there was increased risk of progression compared to those who had baseline lymphopenia but recovered their ALC to greater than 1000 at 3 months with HR $2.76(p<0.05)$ and compared to those who were never lymphopenic with HR $1.50(\mathrm{p}<0.05)$. There was no significant difference in risk of progression between those who were never lymphopenic and those who had baseline lymphopenia but recovered their ALC $(\mathrm{p}=0.85)$. In those patients with no lymphopenia at baseline with new lymphopenia at 3 months, there was increased risk of progression compared to those who were never lymphopenic with HR $2.45(\mathrm{p}<0.01)$ and, interestingly, compared to those who were always lymphopenic at baseline and 3 months with HR $3.09(\mathrm{p}<0.01)$. We also found associations between 
progression and ALC at 3 months as a continuous variable, the difference in ALC between baseline and month 3 after the start of therapy, and the neutrophil to lymphocyte ratio at 3 months as shown in Table 3.

\section{DISCUSSION}

This retrospective single institution analysis was designed to investigate the relationships between absolute
A

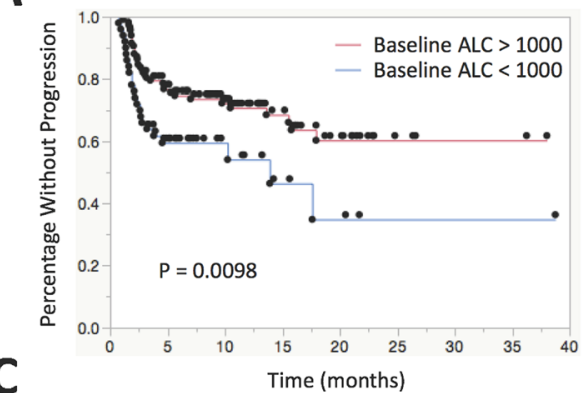

C

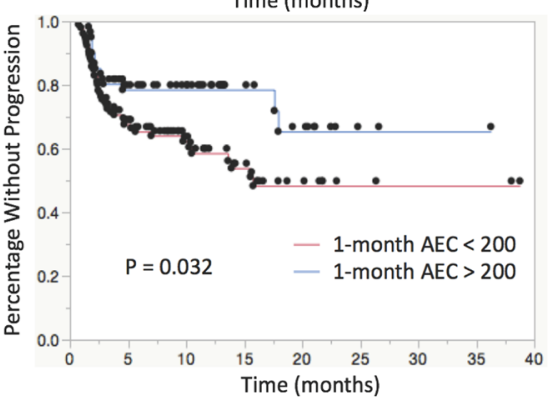

E

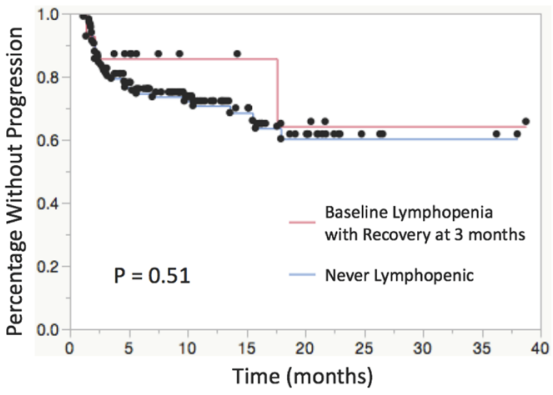

G

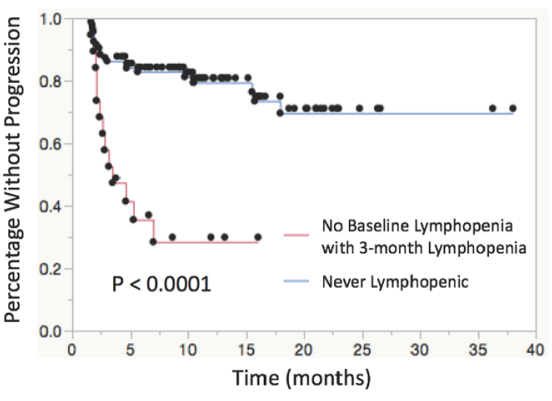

B

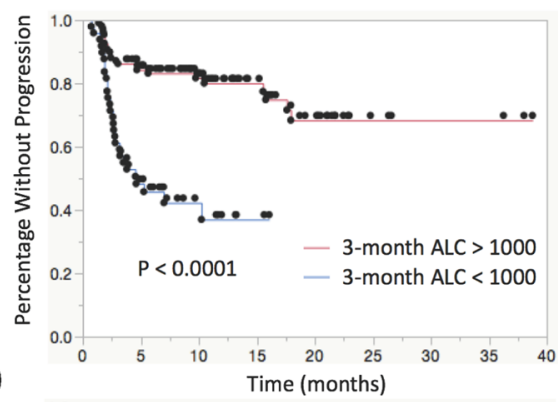

D

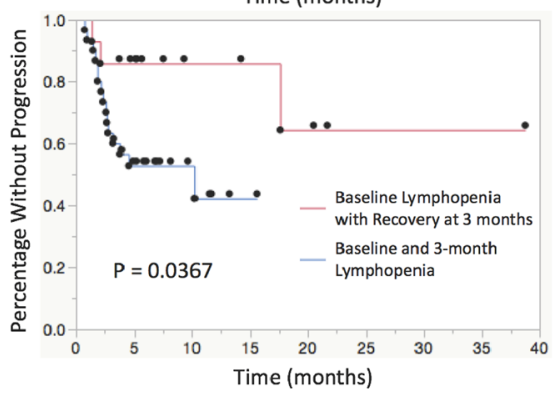

$F$

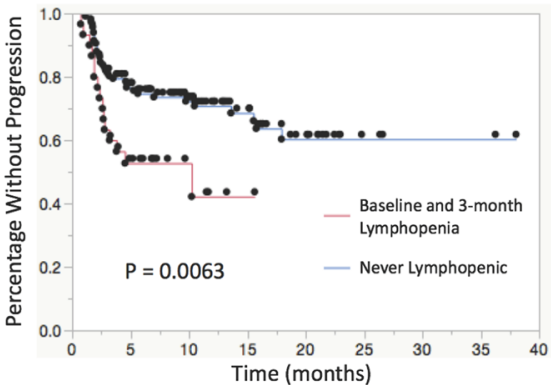

H

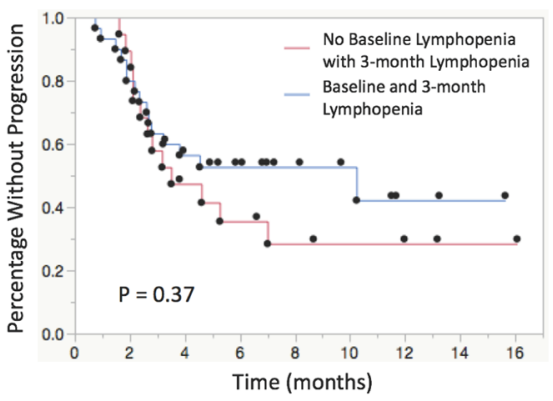

Figure 1: Kaplan-Meier plots for time to progression stratified by various leukocyte subsets. (A) KM plot comparing patients with baseline lymphopenia (ALC < 1000) vs no baseline lymphopenia. (B) KM plot comparing patients with lymphopenia vs no lymphopenia at 3 months after the start of therapy. (C) KM plot comparing patients with AEC $>200$ vs AEC $<200$ at 1 month after the start of therapy. (D) KM plot comparing patients who remain lymphopenic at baseline and 3 months after the start of therapy vs patients with baseline lymphopenia who recover to ALC $>1000$ at 3 months after the start of therapy. (E) KM plot comparing patients with baseline lymphopenia who recover to ALC $>1000$ at 3 months after the start of therapy vs patients that are never lymphopenic at baseline or at 3 months. (F) KM plot comparing patients who remain lymphopenic at baseline and 3 months after the start of therapy vs patients that are never lymphopenic at baseline or at 3 months. (G) KM plot comparing patients who have no baseline lymphopenia who subsequently develop lymphopenia at 3 months after the start of therapy vs patients that are never lymphopenic at baseline or at 3 months. (H) KM plot comparing patients who have no baseline lymphopenia who subsequently develop lymphopenia at 3 months after the start of therapy vs patients who remain lymphopenic at baseline and 3 months after the start of therapy. 
Table 4: Survival analysis by leukocyte subgroups

\begin{tabular}{|c|c|c|c|c|c|c|c|c|}
\hline Categories & $\begin{array}{c}\text { Number } \\
\text { of patients }\end{array}$ & $\begin{array}{l}\text { Percentage } \\
\text { of patients }\end{array}$ & $\begin{array}{l}\text { Median time } \\
\text { to progression }\end{array}$ & $\begin{array}{l}\text { Log rank, } \\
P\end{array}$ & $\begin{array}{l}\% \text { Without progression } \\
\text { at } 12 \text { months }\end{array}$ & $\mathbf{S E}$ & $\begin{array}{c}\text { Low } \\
95 \% \text { CI }\end{array}$ & $\begin{array}{l}\text { High } \\
\mathbf{9 5 \%} \mathrm{CI}\end{array}$ \\
\hline Eosinophils at 1 month $>200$ & 61 & 36.5 & Not reached & \multirow{2}{*}{$\mathrm{P}=0.032$} & 78.5 & 5.3 & 68.1 & 88.9 \\
\hline Eosinophils at 1 month $<200$ & 106 & 63.5 & 15.8 & & 58.6 & 5.3 & 48.3 & 68.9 \\
\hline ALC $>1000$ at baseline & 117 & 70.1 & Not reached & \multirow{2}{*}{$\mathrm{P}=0.0098$} & 70.8 & 4.4 & 62.1 & 79.5 \\
\hline ALC $<1000$ at baseline & 50 & 29.9 & 13.9 & & 54.1 & 8.2 & 38.0 & 70.2 \\
\hline ALC $>1000$ at 3 months & 109 & 69.0 & Not reached & \multirow{2}{*}{$\mathrm{P}<0.0001$} & 80.0 & 4.1 & 72.0 & 88.0 \\
\hline ALC $<1000$ at 3 months & 49 & 31.0 & 4.6 & & 37.0 & 8.2 & 20.8 & 53.1 \\
\hline $\begin{array}{l}\text { Baseline lymphopenia with } \\
\text { persistence at } 3 \text { months }\end{array}$ & 30 & 20.4 & 10.2 & \multirow[t]{2}{*}{$\mathrm{P}=0.0063$} & 42.2 & 12.0 & 18.7 & 65.7 \\
\hline No baseline lymphopenia & 117 & 79.6 & Not reached & & 70.8 & 4.5 & 62.1 & 79.5 \\
\hline $\begin{array}{l}\text { Baseline lymphopenia with } \\
\text { persistence at } 3 \text { months }\end{array}$ & 30 & 68.2 & 10.2 & \multirow{2}{*}{$\mathrm{p}=0.0367$} & 42.1 & 12.0 & 18.6 & 65.6 \\
\hline $\begin{array}{l}\text { Baseline lymphopenia with } \\
\text { recovery at } 3 \text { months }\end{array}$ & 14 & 31.8 & Not reached & & 85.7 & 9.4 & 67.4 & 104.0 \\
\hline $\begin{array}{l}\text { No baseline lymphopenia or } \\
\text { lymphopenia at } 3 \text { month }\end{array}$ & 95 & 83.3 & Not reached & \multirow{2}{*}{$\mathrm{p}<0.0001$} & 79.4 & 4.5 & 70.6 & 88.2 \\
\hline $\begin{array}{l}\text { No baseline lymphopenia with } \\
\text { subsequent lymphopenia at } 3 \text { month }\end{array}$ & 19 & 16.7 & 3.5 & & 28.4 & 11.0 & 6.8 & 50.0 \\
\hline $\begin{array}{l}\text { Baseline lymphopenia with } \\
\text { recovery at } 3 \text { months }\end{array}$ & 14 & 10.7 & Not reached & \multirow[t]{2}{*}{$\mathrm{p}=0.51$} & 85.7 & 9.4 & 67.4 & 104.0 \\
\hline No baseline lymphopenia & 117 & 89.3 & Not reached & & 70.8 & 4.5 & 62.0 & 79.6 \\
\hline $\begin{array}{l}\text { Baseline lymphopenia with } \\
\text { persistence at } 3 \text { months }\end{array}$ & 30 & 61.2 & 10.2 & \multirow[b]{2}{*}{$\mathrm{p}=0.37$} & 28.4 & 11.0 & 6.8 & 50.0 \\
\hline $\begin{array}{l}\text { No baseline lymphopenia with } \\
\text { subsequent lymphopenia at } 3 \text { month }\end{array}$ & 19 & 38.8 & 3.5 & & 42.2 & 12.0 & 18.7 & 65.6 \\
\hline
\end{tabular}

Table of univariate Kaplan-Meier estimates of median survival as well as 1-year survival rate with $95 \%$ confidence interval and p-values derived from the log rank test comparing various leukocyte subgroups.

lymphocyte counts and the toxicity and efficacy of PD-1 inhibitors in patients with solid tumors. Lymphopenia is common in patients with advanced cancers, occurring in approximately $40 \%$ of patients receiving radiation therapy for glioblastoma, head and neck cancer, pancreatic cancer, and non-small cell lung cancer [15]. This lymphopenia is profound, with $40 \%$ of patients having a CD4 count of $<200$ cells $/ \mathrm{mm} 3$, and long-lasting, with low counts commonly persisting for over one year [16].

Our retrospective data suggest that patients with baseline lymphopenia before starting PD-1 inhibitors and those with lymphopenia 3 months after starting therapy may be less likely to benefit from treatment with PD-1 inhibitors, but are also less likely to experience irAEs. Our findings build upon several cohort studies that indicate that peripheral leukocyte populations may be correlated with clinical responses to checkpoint inhibitors. A number of markers for increased ipilimumab efficacy have been described, including high AEC, high ALC and low neutrophil to lymphocyte ratio [17-28]. Similar efforts have been made to predict response to PD-1 inhibitor therapy using peripheral leukocyte counts.
In a retrospective analysis of over 600 patients treated with pembrolizumab for metastatic melanoma, baseline relative eosinophil count $\geq 1.5 \%$ and relative lymphocyte count $\geq 17.5 \%$ were found to be correlated with favorable overall survival [29]. In a separate retrospective study of 173 patients with metastatic melanoma treated with checkpoint inhibitors, the presence of eosinophilia at any point in the course of therapy correlated with longer survival [30]. In another retrospective study of 98 patients with unresectable stage III or IV melanoma treated with nivolumab, absolute lymphocyte count $>1000$ and absolute neutrophil count $<4000$ early in the course of therapy at week 3 and 6 were found to be markers of favorable response [31]. These associations require confirmation in prospective clinical trials of immune checkpoint inhibitors.

Additional research is also needed to understand potential mechanisms through which lymphopenia could affect progression free survival for patients receiving an immune checkpoint inhibitor. One hypothesis is that lymphopenia may reflect a state of $\mathrm{T}$ cell dysfunction resulting from immune exhaustion and depletion of antitumor lymphocytes, and that these dysfunctional 
lymphocytes have a limited ability to exert an anti-tumor effect in the setting of PD-1 inhibitor therapy [32]. If this hypothesis is correct, strategies that rescue the $\mathrm{T}$ cell repertoire and induce novel $\mathrm{T}$ cells capable of an anti-tumor response, such as adoptive cell therapies and vaccination, may be necessary to improve upon response rates in patients with lymphopenia receiving an immune checkpoint inhibitor [33]. Alternatively, lymphopenia may be a prognostic marker resulting from inflammation or other factors that reflect an advanced disease stage. Lymphopenia has been related to survival in a variety of clinical settings, including patients not receiving immune checkpoint inhibitors [15, 34].

In summary, our data indicate that patients with higher baseline lymphocyte counts may have a greater risk for irAE, whereas patients with lymphopenia at baseline and persistent lymphopenia while on therapy have a shorter time to progression on these agents. This analysis has several limitations. This is a single institution study and is therefore subject to the risks of regional and site-specific influences. In addition, given the retrospective nature of the study, we cannot control for patient selection procedures. Furthermore, known prognostic factors that could affect outcome such as ECOG performance status, burden or site of metastases, and PD-L1 status of the tumors were not analyzed in this study. Prospective validation of our results in patients with solid tumors is needed to confirm and expand upon our findings, and improved understanding of the immunology behind this association may lead to the development of more effective therapies for these patients.

\section{MATERIALS AND METHODS}

We performed an IRB-approved retrospective chart review of adult solid tumor patients treated with nivolumab or pembrolizumab at a single institution from January 2015 until November 2016. Solid tumor types that were included were those with FDA approved indications for PD-1 or PD-L1 inhibitor therapy including squamous and nonsquamous non-small-cell lung cancer, melanoma, renal cell carcinoma, urothelial carcinoma, HNSCC, Merkel cell and mismatch repair deficient (MMR-d) colon cancer. Patients were excluded if they were receiving PD-1 inhibitors: (a) for hematologic malignancies, (b) concurrently with investigational immunotherapies, (c) on unreported clinical trials, (d) in cancers for which the activity of immune checkpoint inhibitors remains unclear, or (e) for less than two doses of either nivolumab or pembrolizumab. We chose to include patients who received concurrent ipilimumab or had received ipilimumab in a prior line of therapy. Patients were treated until disease progression or until unacceptable toxicity occurred per the discretion of the individual oncologist. Data were collected on patient demographics and treatment history including prior chemotherapy and radiation treatment, response to therapy, adverse events, and leukocyte counts. Response to PD-1 inhibitor therapy was defined using RECIST 1.1 criteria based on imaging done from the start of PD-1 inhibitor therapy to the date of progressive disease or start of a new systemic treatment [13]. Using the RECIST 1.1 criteria, the best response achieved was recorded for each patient and time to response was defined as the earliest time point at which the partial response or complete response category was first achieved. The interval of imaging studies was at the discretion of the individual oncologist but for most patients was approximately every 3 months. Immune-related adverse events (irAE) were defined as adverse events with a potential immunologic basis. Grading of these events used the National Cancer Institute Common Terminology Criteria for Adverse Events (CTCAE) v.4.0 [14]. Data were collected on time to onset of the irAE and subsequent management including requirement for immunosuppressive therapy, PD-1 inhibitor discontinuation, or hospitalization. Leukocyte counts were retrospectively collected at baseline, and at 1, 3 and 6 months after the start of therapy.

Follow-up time was defined from the date of the first dose of PD-1 inhibitor therapy to the date of last known contact or death. Survival probabilities and median survival with $95 \%$ confidence intervals (CI) were estimated according to the Kaplan-Meier method, and compared using log-rank tests. Hazard ratios were calculated using the Cox proportional hazards model with $\mathrm{P}$ values based on the Wald test. There were no deaths in our cohort that were not considered secondary to cancer. $\mathrm{P}$ values for univariate analyses with logistic regression models as well as multivariate regression models were obtained using the likelihood ratio test. $\mathrm{P}$ values for univariate analyses with binary variables were calculated using a 2-tail Fisher's exact test. For univariate analyses with a continuous dependent variable, the $t$ test was used for $\mathrm{P}$ value calculation. Throughout the analysis, $\mathrm{P}$ values less than 0.05 were considered statistically significant. All statistical analyses were performed using JMP software (version 12; SAS institute, Cary, NC).

\section{Abbreviations}

PD-1 = programmed cell death 1 , PD-L1 = programmed cell death ligand 1, CTLA-4 = cytotoxic T-lymphocyte-associated protein 4 , irAE $=$ immune related adverse events, ALC = absolute lymphocyte count, $\mathrm{AEC}=$ absolute eosinophil count, $\mathrm{ANC}=$ absolute neutrophil count, $\mathrm{HR}=$ hazard ratio, $\mathrm{OR}=$ odds ratio, $\mathrm{CI}=$ confidence interval, MMR-d = mismatch repair deficient, $\mathrm{HNSCC}=$ head and neck squamous cell carcinoma, RCC $=$ renal cell carcinoma, NSCLC $=$ non-small cell lung cancer, $\mathrm{ECOG}=$ Eastern Cooperative Oncology Group.

\section{Author contributions}

Conception or design of the work: AD, MY, SAG

Data collection: AD, MY, SAG 
Data analysis and interpretation: AD, MY, AH, EJ, SAG

Drafting the article: AD, MY, AH, EJ, SAG

Critical revision of the article: AD, MY, AH, EJ, SAG

Final approval of the version to be published: $A D$, MY, AH, EJ, SAG.

\section{CONFLICTS OF INTEREST}

AD: No relevant conflicts of interest

MY: Receives research support from Bristol Myers

Squibb, Exelixis, and Merck Pharmaceuticals.

AH: No relevant conflicts of interest

EJ: Under a licensing agreement between Aduro BioTech, Inc. and the Johns Hopkins University and E.M.J., the University is entitled to milestone payments and royalty on sales of certain cancer vaccine products.

SAG: No relevant conflicts of interest.

\section{FUNDING}

This research was supported by the Linda Rubin Fellowship Fund. This work was partially supported by a National Institutes of Health grant (T32 CA009071, to M.Y., and P30CA006973, to S.G.).

\section{REFERENCES}

1. Topalian SL, Drake CG, Pardoll DM. Immune checkpoint blockade: a common denominator approach to cancer therapy. Cancer Cell. 2015; 27:450-61. https://doi. org/10.1016/j.ccell.2015.03.001.

2. Wang C, Thudium KB, Han M, Wang XT, Huang H, Feingersh D, Garcia C, Wu Y, Kuhne M, Srinivasan M, Singh S, Wong S, Garner N, et al. In vitro characterization of the anti-PD-1 antibody nivolumab, BMS-936558, and in vivo toxicology in non-human primates. Cancer Immunol Res. 2014; 2:846-56. https://doi.org/10.1158/2326-6066. CIR-14-0040.

3. Brahmer J, Reckamp KL, Baas P, Crinò L, Eberhardt WE, Poddubskaya E, Antonia S, Pluzanski A, Vokes EE, Holgado E, Waterhouse D, Ready N, Gainor J, et al. Nivolumab versus docetaxel in advanced squamous-cell non-small-cell lung cancer. N Engl J Med. 2015; 373:12335. https://doi.org/10.1056/NEJMoa1504627.

4. Larkin J, Chiarion-Sileni V, Gonzalez R, Grob JJ, Cowey CL, Lao CD, Schadendorf D, Dummer R, Smylie M, Rutkowski P, Ferrucci PF, Hill A, Wagstaff J, et al. Combined nivolumab and ipilimumab or monotherapy in untreated melanoma. N Engl J Med. 2015; 373:23-34. https://doi.org/10.1056/NEJMoa1504030.

5. McDermott DF, Drake CG, Sznol M, Choueiri TK, Powderly JD, Smith DC, Brahmer JR, Carvajal RD, Hammers HJ, Puzanov I, Hodi FS, Kluger HM, Topalian $\mathrm{SL}$, et al. Survival, durable response, and long-term safety in patients with previously treated advanced renal cell carcinoma receiving nivolumab. J Clin Oncol. 2015; 33:2013-20. https://doi.org/10.1200/JCO.2014.58.1041.

6. Postow MA, Chesney J, Pavlick AC, Robert C, Grossmann K, McDermott D, Linette GP, Meyer N, Giguere JK, Agarwala SS, Shaheen M, Ernstoff MS, Minor D, et al. Nivolumab and ipilimumab versus ipilimumab in untreated melanoma. N Engl J Med. 2015; 372:2006-17. https:/doi. org/10.1056/NEJMoa1414428.

7. Topalian SL, Hodi FS, Brahmer JR, Gettinger SN, Smith DC, McDermott DF, Powderly JD, Carvajal RD, Sosman JA, Atkins MB, Leming PD, Spigel DR, Antonia SJ, et al. Safety, activity, and immune correlates of anti-PD-1 antibody in cancer. N Engl J Med. 2012; 366:2443-54. https://doi.org/10.1056/NEJMoa1200690.

8. Weber JS, D'Angelo SP, Minor D, Hodi FS, Gutzmer R, Neyns B, Hoeller C, Khushalani NI, Miller WH, Lao CD, Linette GP, Thomas L, Lorigan P, et al. Nivolumab versus chemotherapy in patients with advanced melanoma who progressed after anti-CTLA-4 treatment (CheckMate 037): a randomised, controlled, open-label, phase 3 trial. Lancet Oncol. 2015; 16:375-84. https://doi.org/10.1016/ S1470-2045(15)70076-8.

9. Wolchok JD, Kluger H, Callahan MK, Postow MA, Rizvi NA, Lesokhin AM, Segal NH, Ariyan CE, Gordon RA, Reed K, Burke MM, Caldwell A, Kronenberg SA, et al. Nivolumab plus ipilimumab in advanced melanoma. N Engl J Med. 2013; 369:122-33. https://doi.org/10.1056/ NEJMoa1302369.

10. Donin NM, Lenis AT, Holden S, Drakaki A, Pantuck A, Belldegrun A, Chamie K. Immunotherapy for the treatment of urothelial carcinoma. J Urol. 2017; 197:14-22. https:// doi.org/10.1016/j.juro.2016.02.3005.

11. Sukari A, Nagasaka M, Al-Hadidi A, Lum LG. Cancer immunology and immunotherapy. Anticancer Res. 2016; 36:5593-606. https://doi.org/10.21873/anticanres.11144.

12. Hofmann L, Forschner A, Loquai C, Goldinger SM, Zimmer L, Ugurel S, Schmidgen MI, Gutzmer R, Utikal JS, Göppner D, Hassel JC, Meier F, Tietze JK, et al. Cutaneous, gastrointestinal, hepatic, endocrine, and renal side-effects of anti-PD-1 therapy. Eur J Cancer. 2016; 60:190-209. https:// doi.org/10.1016/j.ejca.2016.02.025.

13. Eisenhauer EA, Therasse P, Bogaerts J, Schwartz LH, Sargent D, Ford R, Dancey J, Arbuck S, Gwyther S, Mooney M, Rubinstein L, Shankar L, Dodd L, et al. New response evaluation criteria in solid tumours: revised RECIST guideline (version 1.1). Eur J Cancer. 2009; 45:228-47. https://doi.org/10.1016/j.ejca.2008.10.026.

14. NCI Common Terminology Criteria for Adverse Events (CTCAE) v.4 data files. Bethesda, MD: National Cancer Institute. 2010. Available 2016 Jan 12, from http://evs.nci. nih.gov/ftp1/CTCAE/About.html.

15. Grossman SA, Ellsworth S, Campian J, Wild AT, Herman JM, Laheru D, Brock M, Balmanoukian A, Ye X. Survival 
in patients with severe lymphopenia following treatment with radiation and chemotherapy for newly diagnosed solid tumors. J Natl Compr Canc Netw. 2015; 13:1225-31. http:// www.ncbi.nlm.nih.gov/pubmed/26483062.

16. Grossman SA, Ye X, Lesser G, Sloan A, Carraway H, Desideri S, Piantadosi S; NABTT CNS Consortium. Immunosuppression in patients with high-grade gliomas treated with radiation and temozolomide. Clin Cancer Res. 2011; 17:5473-80. https://doi.org/10.1158/1078-0432. CCR-11-0774.

17. Ku GY, Yuan J, Page DB, Schroeder SE, Panageas KS, Carvajal RD, Chapman PB, Schwartz GK, Allison JP, Wolchok JD. Single-institution experience with ipilimumab in advanced melanoma patients in the compassionate use setting: lymphocyte count after 2 doses correlates with survival. Cancer. 2010; 116:1767-75. https://doi. org/10.1002/cncr.24951.

18. Kitano S, Postow MA, Ziegler CG, Kuk D, Panageas KS, Cortez C, Rasalan T, Adamow M, Yuan J, Wong P, AltanBonnet G, Wolchok JD, Lesokhin AM. Computational algorithm-driven evaluation of monocytic myeloidderived suppressor cell frequency for prediction of clinical outcomes. Cancer Immunol Res. 2014; 2:812-21. https:// doi.org/10.1158/2326-6066.CIR-14-0013.

19. Wilgenhof S, Du Four S, Vandenbroucke F, Everaert H, Salmon I, Liénard D, Marmol VD, Neyns B. Singlecenter experience with ipilimumab in an expanded access program for patients with pretreated advanced melanoma. J Immunother. 2013; 36:215-22. https://doi.org/10.1097/ CJI.0b013e31828eed39.

20. Martens A, Wistuba-Hamprecht K, Geukes Foppen M, Yuan J, Postow MA, Wong P, Romano E, Khammari A, Dreno B, Capone M, Ascierto PA, Di Giacomo AM, Maio $\mathrm{M}$, et al. Baseline peripheral blood biomarkers associated with clinical outcome of advanced melanoma patients treated with ipilimumab. Clin Cancer Res. 2016; 22:2908-18. https://doi.org/10.1158/1078-0432. CCR-15-2412.

21. Delyon J, Mateus C, Lefeuvre D, Lanoy E, Zitvogel L, Chaput N, Roy S, Eggermont AM, Routier E, Robert C. Experience in daily practice with ipilimumab for the treatment of patients with metastatic melanoma: an early increase in lymphocyte and eosinophil counts is associated with improved survival. Ann Oncol. 2013; 24:1697-703. https://doi.org/10.1093/ annonc/mdt027.

22. Martens A, Wistuba-Hamprecht K, Yuan J, Postow MA, Wong P, Capone M, Madonna G, Khammari A, Schilling B, Sucker A, Schadendorf D, Martus P, Dreno B, et al. Increases in absolute lymphocytes and circulating CD4+ and CD8+ T Cells are associated with positive clinical outcome of melanoma patients treated with ipilimumab. Clin Cancer Res. 2016; 22:4848-58. https://doi.org/10.1158/1078-0432. CCR-16-0249.

23. Berman D, Wolchok J, Weber J, Hamid O, O'Day S, Chasalow S. Association of peripheral blood absolute lymphocyte count (ALC) and clinical activity in patients with advanced melanoma treated with ipilimumab (Abstract). J Clin Oncol. 2009. http://meetinglibrary.asco. org/content/34257-65.

24. Di Giacomo AM, Calabrò L, Danielli R, Fonsatti E, Bertocci E, Pesce I, Fazio C, Cutaia O, Giannarelli D, Miracco C, Biagioli M, Altomonte M, Maio M. Longterm survival and immunological parameters in metastatic melanoma patients who responded to ipilimumab $10 \mathrm{mg} / \mathrm{kg}$ within an expanded access programme. Cancer Immunol Immunother. 2013; 62:1021-8. https://doi.org/10.1007/ s00262-013-1418-6.

25. Liakou CI, Kamat A, Tang DN, Chen H, Sun J, Troncoso P, Logothetis C, Sharma P. CTLA-4 blockade increases IFNgamma-producing CD4+ICOShi cells to shift the ratio of effector to regulatory $\mathrm{T}$ cells in cancer patients. Proc Natl Acad Sci U S A. 2008; 105:14987-92. https://doi. org/10.1073/pnas.0806075105.

26. Gebhardt C, Sevko A, Jiang H, Lichtenberger R, Reith M, Tarnanidis K, Holland-Letz T, Umansky L, Beckhove P, Sucker A, Schadendorf D, Utikal J, Umansky V. Myeloid cells and related chronic inflammatory factors as novel predictive markers in melanoma treatment with ipilimumab. Clin Cancer Res. 2015; 21:5453-9. https://doi. org/10.1158/1078-0432.CCR-15-0676.

27. Tarhini AA, Edington H, Butterfield LH, Lin Y, Shuai Y, Tawbi H, Sander C, Yin Y, Holtzman M, Johnson J, Rao UN, Kirkwood JM. Immune monitoring of the circulation and the tumor microenvironment in patients with regionally advanced melanoma receiving neoadjuvant ipilimumab. PLoS One. 2014; 9:e87705. https://doi.org/10.1371/journal. pone. 0087705 .

28. Sarnaik AA, Yu B, Yu D, Morelli D, Hall M, Bogle D, Yan L, Targan S, Solomon J, Nichol G, Yellin M, Weber JS. Extended dose ipilimumab with a peptide vaccine: immune correlates associated with clinical benefit in patients with resected high-risk stage IIIc/IV melanoma. Clin Cancer Res. 2011; 17:896-906. https://doi.org/10.1158/1078-0432. CCR-10-2463.

29. Weide B, Martens A, Hassel JC, Berking C, Postow MA, Bisschop K, Simeone E, Mangana J, Schilling B, Di Giacomo AM, Brenner N, Kähler KC, Heinzerling $\mathrm{L}$, et al. Baseline biomarkers for outcome of melanoma patients treated with pembrolizumab. Clin Cancer Res. 2016; 22:5487-96. https://doi.org/10.1158/1078-0432. CCR-16-0127.

30. Moreira A, Leisgang W, Schuler G, Heinzerling L. Eosinophilic count as a biomarker for prognosis of melanoma patients and its importance in the response to immunotherapy. Immunotherapy. 2017; 9:115-21. https:// doi.org/10.2217/imt-2016-0138.

31. Nakamura Y, Kitano S, Takahashi A, Tsutsumida A, Namikawa K, Tanese K, Abe T, Funakoshi T, Yamamoto N, Amagai M, Yamazaki N. Nivolumab for advanced melanoma: pretreatment prognostic factors and early 
outcome markers during therapy. Oncotarget. 2016; 7:77404-15. https://doi.org/10.18632/oncotarget.12677.

32. Schietinger A, Greenberg PD. Tolerance and exhaustion: defining mechanisms of $\mathrm{T}$ cell dysfunction. Trends Immunol. 2014; 35:51-60. https://doi.org/10.1016/j. it.2013.10.001.

33. Yarchoan M, Johnson BA, Lutz ER, Laheru DA, Jaffee EM. Targeting neoantigens to augment antitumour immunity.
Nat Rev Cancer. 2017; 17:209-22. https://doi.org/10.1038/ nrc.2016.154.

34. Campian JL, Sarai G, Ye X, Marur S, Grossman SA. Association between severe treatment-related lymphopenia and progression-free survival in patients with newly diagnosed squamous cell head and neck cancer. Head Neck. 2014; 36:1747-53. https://doi.org/10.1002/hed.23535. 